\title{
Seismic risk: the biases of earthquake media coverage
}

\author{
Maud H. Devès ${ }^{1,2}$, Marion Le Texier ${ }^{3}$, Hugues Pécout ${ }^{4}$, and Claude Grasland ${ }^{4,5}$ \\ ${ }^{1}$ Université de Paris, Institut de Physique du Globe de Paris, CNRS UMR 7154, 75005 Paris, France \\ ${ }^{2}$ Université de Paris, Institut Humanités Sciences Sociétés, Centre de Recherche Psychanalyse Médecine et Société, \\ CNRS EA 3522, 75013 Paris, France \\ ${ }^{3}$ Université de Rouen Normandie, UMR CNRS 6266 IDEES, 76781 Mont-Saint-Aignan CEDEX, France \\ ${ }^{4}$ Université de Paris, Collège international des sciences territoriales, CNRS FR 2007, 75013 Paris, France \\ ${ }^{5}$ Université de Paris, Géographie-Cités, UMR 8504, 75006 Paris, France
}

Correspondence: Maud H. Devès (deves@ipgp.fr)

Received: 27 March 2019 - Discussion started: 17 April 2019

Accepted: 6 July 2019 - Published: 15 August 2019

Abstract. The capacity of individuals to cope with threatening situations depends directly on their capacity to anticipate what will come next. The media should play a key role in that respect, but an extensive analysis of earthquake media coverage by the international news reveals systematic biases. Exploring a corpus of 320888 news articles published by 32 worldwide newspapers in 2015 in English, Spanish or French, we found that the press covers a very small number of events: $71 \%$ of the news about seismic events was dedicated to only 3 earthquakes (among the 1559 magnitude 5+ events). A combination of frequency and content analysis reveals a typical framing of the "earthquake news". Except for the "Nepal quake", the duration of the coverage is usually very short. Thus, the news tends to focus on short-term issues: the event magnitude, tsunami alerts, human losses, material damage and rescue operations. Longerterm issues linked to the recovery, restoration, reconstruction, mitigation and prevention are barely addressed. Preventive safety measures are almost never mentioned. The news on impacts shows a peculiar appetency for death counts, material damage estimates and sensationalism. News on the response tends to emphasize the role played by the international community in helping the "poor and vulnerable". The scientific content of the coverage is often restricted to mentions of the magnitude, with the concept of the seismic intensity being largely ignored. The notion of the "seismic crisis" also seems unclear, with aftershocks sometimes being treated as isolated events. Secondary hazards are barely mentioned, except in the case of tsunami alerts. Together, these biases contribute to fatalistic judgments that damage cannot be pre- vented. If scientific messages are to be communicated, they should be broadcast a few hours after an event. Why not take the opportunity to familiarize people with the real timeline of seismic disasters?

\section{Introduction}

\subsection{Newspapers play a key role in times of disaster}

Despite the increasing influence of social media, newspapers remain major gatekeepers in the process of selection and dissemination of the news proposed by press agencies to national and local audiences (Harcup and O'Neill, 2017). For risk managers, they remain an important tool for reaching a wide range of people (Cottle, 2014). Hence, one can expect the press not only to inform, but also to provide the public with the knowledge required to reduce disaster risks (see, for instance, the media kit created by the Asian Disaster Preparedness Center and the Department of Disaster Management and Climate Change of the Ministry of Natural Resources and Environment of Lao PDR, Thanthathep et al., 2016).

Numerous studies have explored the ability of the news media to influence public perception. According to McClure et al. (2001) and McClure and Velluppillai (2013), public education programs and news reports often describe disasters "in ways that accentuate the extent and severity of damage", thus contributing to "fatalistic attributions and judgments that the damage cannot be prevented". Improper attribution can hinder peoples' preparedness: "When people attribute dam- 
age to an earthquake's magnitude, they invoke an uncontrollable cause, but when they attribute damage to human design, they invoke a relatively controllable cause". For authors such as Gaddy and Tanjong (1987) or Hiori et al. (1985), understanding how the media reports on disaster situations has direct implications as it shows "how [the] agencies [involved in disaster risk reduction] could reduce fatalism and facilitate preventive action by the way they present information about earthquakes and other disasters".

It is not uncommon to hear scientists criticizing the press for conveying distorted messages (e.g., Smith, 1996; Cocco et al., 2015; Harris, 2015a, b). Journalists have even been accused of playing the role of "crisis catalyst" (Boin et al., 2008). Comparing the news treatment of a real earthquake with that of a false quake prediction, Smith (1996) concluded that "the interest in drama at the expense of public affairs interferes with good scientific reporting". In general, scientists denounce the tendency of the press to search for "culprits" and "accountability" and for "stirring up old rivalry and exaggerating conflicts" (Harris, 2015a, b). Harris (2015a) showed how the placement of the information in the frame of the pages, the selection of stories, the use of sources, the selection of data, exaggeration, omissions and preferences for certain sources or pieces of information contribute to the oversimplification of scientifically complex arguments and an orientation toward information interpretations forcing inclination or prejudice for, or against, an argument, person or group, putting a particular emphasis on some aspects of the situation. Harris (2015b) concluded that what he calls the "media filter" can influence the public understanding of scientific uncertainties and argued that a careful study of the media coverage would help scientists to communicate in a manner that reduces the chance of misunderstanding.

\subsection{Earthquake media coverage and international news flow theory}

This study, led by a multidisciplinary team of researchers from geophysics, psychology and geography backgrounds, builds on previous results (Devès, 2015; Grasland et al., 2016; Le Texier et al., 2016) to address the following question: in a globalized world, can we find systematic trends in how the international news published by daily newspapers covers earthquake events?

By "international news", we mean news published by daily newspapers about foreign countries or, in practical terms, news published by newspapers through specific RSS flows entitled "international" or "world". Many hypotheses about the rules governing the international news flow were formulated more than 50 years ago (Galtung and Ruge, 1965; Östgaard, 1965) and verified by empirical studies concerning the unequal salience of countries in the media and the effects of size, proximity and the preference for elite countries or negative news (Peterson, 1981; Kim and Barnett, 1996; Wu,
2000). The development of new forms of electronic communication has not modified the previously observed rules, and recent works have confirmed that the circulation of international news is still very influenced by cultural factors such as language and physical factors such as the distance between the location of the media and the location of events (Segev, 2016; Grasland et al., 2016). However, the salience of countries is generally manifested over a mixture of heterogeneous events, and some authors have focused on subsets of events that are either mentioned or ignored by the media. The event-oriented approach is based on a selection of foreign news related to a specific topic for which it is possible to define a finite and possibly objective list of events occurring in the "real" world. One of the most interesting areas of research from this perspective is the study of the media coverage of earthquakes, for which objective measures of the magnitude or victims are regularly published. Thus, it is possible to analyze the level of newsworthiness according to the general laws postulated by Galtung and its followers (Galtung and Ruge, 1965; Harcup and O'Neill, 2001, 2017; $\mathrm{Wu}, 2000)$ and their specific application to earthquake media coverage (Koopmans and Vliegenthart, 2010). Examining the news media coverage of more than 900 earthquakes, Le Texier et al. (2016) showed that the event severity (reported in the press as a moment magnitude, $M_{\mathrm{w}}$ affected the volume of media coverage following a power law. Studying the dynamics of public interest in major earthquakes using Google Trends, Tan and Maharjan (2018) found that the duration and search peak vary with the death toll and damage but not with the earthquake magnitude. Earle et al. (2010) found the same pattern for the $2009 M_{\mathrm{w}} 4.3$ Morgan Hill (California) earthquake using Twitter data, from a period of only a dozen minutes.

This paper goes further in questioning the existence of systematic trends in how earthquakes are covered by international news. More specifically, we look into the temporal dynamics of the coverage (duration, trends) and into the potential existence of a typical framing of "earthquake news" (i.e., by comparing news content between events and between newspapers from various countries and languages). Section 2 presents the datasets we use and the main steps we follow for data analysis. First, we analyze the intensity, time distribution and content of a large corpus of approximately 320888 news items published by 32 international news media RSS feeds in 2015. Second, we associate a statistical analysis of the news frequency with a textual analysis of the content of the news. Section 3 describes the main results, and these results are then discussed in Sect. 4. Section 5 concludes the paper. 


\section{Materials and methods}

\subsection{Presentation of the datasets}

The datasets run from 1 January 2015 at 00:00:01 to 31 December 2015 at 23:59:59 UTC. The year 2015 is particularly interesting as it is the year of the Nepal quake, a major event that was well covered by the international news published by daily newspapers. The geophysical dataset is built from the online seismic catalogue provided by the United States Geological Survey (USGS). For each earthquake, we collect the following parameters: hypocenter, magnitude and label. The media dataset is built from the ANR corpus GEOMEDIA, which contains information published by more than 330 news RSS feeds from 180 media outlets, localized in 61 countries and written in 10 languages over 3 years - the information was gathered between 2012 and 2015 as part of the ANR-12-CORP-0009 project, which was coordinated by Claude Grasland. We selected international news media RSS feeds based on several criteria: national or international status of newspapers (broadsheet newspapers), RSS feed regularity, media localization and the volume of information transmitted (see the Supplement of Grasland, 2019). The final corpus consists of 32 RSS feeds related to international news in three languages (English, French and Spanish) that are equitably geographically distributed, according to the possibilities offered by the initial database (Fig. 1). Analyses were completed using R software, notably the "tm" package for text mining.

\subsection{Data cleaning and selection through tagging}

Before starting the data analysis, three processing steps were required (Fig. 2). First, some of the selected RSS news items were not worth analyzing because they were totally devoid of information, simply advertising or summarizing a heterogeneous set of news of the day. These items were deleted from the corpus. Second, the initial database continuously collects RSS items on newspaper websites, and a similar item can be published several times without changes. Therefore, we had to delete all of the duplicate items (items with the same title and text). During these two processing steps, more than 60000 news items were deleted. After cleaning, the dataset contained 320888 news items. To build the joint corpus (referred to as EQ-MEDIA in the following), we then enriched the news media dataset using a two-step tagging process as follows: (1) the geographical tagging of all countries mentioned using word dictionaries and (2) the thematic tagging of all news mentioning a seismic event using an "earthquake dictionary". The first dictionary was tested and validated in previous research (Grasland et al., 2016). The latter was manually tested on $1 \%$ of the total number of news items to determine the number of false positives (i.e., items containing metaphoric references to earthquakes such as a "political earthquake"). We found a reasonable error rate of approx- imately $4 \%$. The rate of false negatives (i.e., missed items) was even smaller (approximately $2 \%$ to $3 \%$ ). The final number of news items dedicated to earthquakes over the year 2015 was 4411 , which represented $1.37 \%$ of the total number of news items published during that time period by all the RSS feeds of the corpus.

\subsection{Two levels of analysis: the year 2015 and three major events}

An analysis of the intensity and duration of coverage was undertaken on the whole EQMEDIA corpus. The analysis of the news content, which required coupled qualitative and quantitative approaches, was undertaken on a selection of earthquakes. As shown in Fig. 3, the "earthquake news" was not evenly distributed over time. Three earthquakes garnered the most attention:

The Gorkha earthquake: Nepal and neighboring countries witnessed a 7.8 magnitude earthquake on 25 April 2015. It was followed by many aftershocks, among which one on 12 May had a magnitude of 7.3. These earthquakes killed more than 9000 people and affected at least 8 million, impacting the main economic and political center of the country (Katmandu) and causing massive economic losses (half of the GDP of the country) (CRED, 2017). The first quake (25 April) was the most devastating. It also triggered landslides and avalanches in the mountains, killing hundreds of people, some of which were foreign tourists whose fates most interested the news media. The magnitude of the main shock was similar to that of the 1934 earthquake.

The Ilapel earthquake: an earthquake of magnitude 8.3 hit the area of Ilapel, Chile, on 9 September 2015, killing at least 15 people and affecting thousands. Chilean authorities ordered the immediate evacuation of the coast due to a tsunami threat. Pacific-wide tsunami warnings were issued, and the evacuation affected approximately 1 million people.

The Hindu Kush earthquake: an earthquake of magnitude 7.5 hit the Hindu Kush region between Afghanistan and Pakistan on 26 October 2015. The earthquake and its aftershocks killed approximately 400 people and affected thousands in Afghanistan, Pakistan and the neighboring countries (including India and Tajikistan).

\subsection{Analyzing the news content}

To more closely examine our dataset, we adopted a method inspired by Cox et al. (2008), who analyzed the print-news media coverage of the recovery process following a forest fire. The first step was to conduct a careful analysis of the content of the news itself to identify thematic patterns but also possible "textual silences", defined by Huckin (2002) as "the omission of some piece of information that is pertinent to the topic at hand". As we were dealing with thousands of news items, this qualitative approach was complemented by a quantitative analysis based on keywords. 


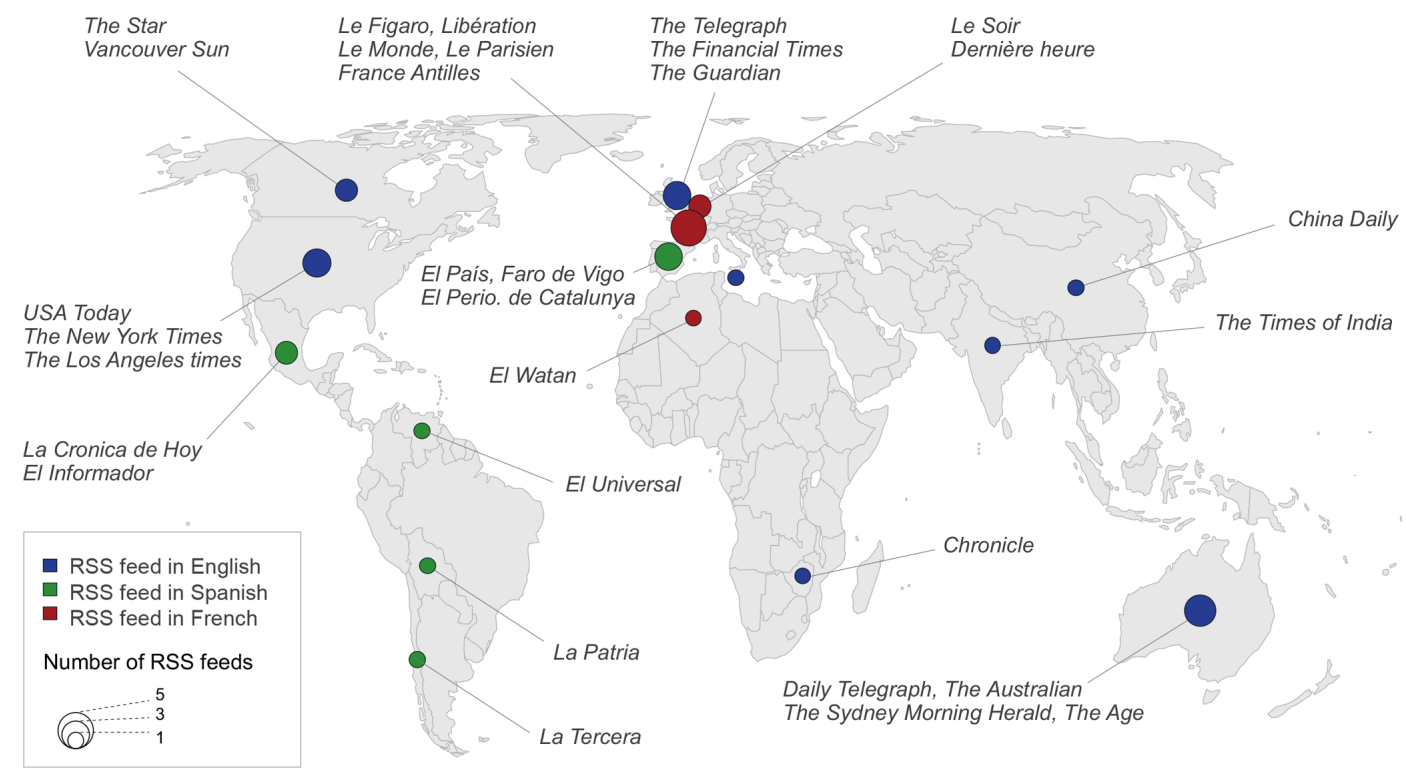

Figure 1. Corpus of news RSS feeds used, by origin and language.

It was possible but ultimately not relevant to proceed to a classification of the content of our thousands of news items with inductive exploratory methods such as cluster analysis (Wilks, 2011) or latent Dirichlet allocation (Blei et al., 2003). Thus, we chose a deductive approach where we tried to extract the categories or concepts defined by experts on disasters from the news media coverage. Following Haas et al. (1977) and Kates et al. (2006), we define six expected categories of content: hazards, impacts, emergency response, restoration, reconstruction and preparedness. The hazards category refers to the seismic phenomenon itself or to any hazardous event it can trigger, such as tsunamis or landslides. The impacts category refers to the immediate effects of these hazards: human loss, injuries, and damage to buildings and infrastructure. The emergency response category refers to the actions taken during or immediately after the earthquake to save lives, reduce health impacts, ensure public safety and meet the basic subsistence needs of the people affected. The rehabilitation category includes recovery and restoration, i.e., actions taken to restore basic services and facilities and improve the livelihoods and health, as well as economic, physical, social, cultural and environmental assets, systems and activities, of the earthquake-affected community. By reconstruction, we mean the medium- and long-term rebuilding and restoration of the critical infrastructure, services, housing, facilities and livelihoods. Preparedness refers to actions carried out to establish the capacities needed to efficiently manage future emergencies. News may refer to one or several of these categories of content.

We classify the most frequently used words of the "earthquake news" into one of these categories of content and build two keyword dictionaries: a discourse content dictionary, corresponding to the above categories (Table 1), and an identity matrix, dedicated to different categories of stakeholders focused on (or forgotten) by the media coverage (Table 2). For this work to be manageable within a reasonable time frame, we adopt a threshold of a minimum of four occurrences in French and Spanish and eight in English (there are 619 and 478 news items in Spanish and French, respectively, so the threshold remains very low, as it corresponds to words occurring in at least $0.36 \%$ of the news items. There are 2097 items in English; thus, the threshold remains the same: it corresponds to words occurring in at least $0.38 \%$ of the news items). Conjunctions and adverbs are not considered, and words with common roots are treated together. We use words that are representative of one and only one of our categories of discourse (principle of exclusivity) and that do not introduce too many false positives. Tagging the database using these two keyword dictionaries allows us to quantify the presence/absence and evolution of each theme/subtheme/topic. There are limitations to this keyword approach (the meaning of isolated words is often ambiguous and related to the context and the position before or after other words, e.g., Church and Hanks, 1990) but the independent classification of the news items by the co-authors indicates good consistency in the coding of themes and subthemes and the identification of topics (we reach a maximum of $12 \%$ of differences for the emergency response category).

\section{Results}

\section{1 "Earthquake news" analysis of temporality}

News concentrates on a very small number of earthquakes. A total of $71.4 \%$ of the news items about seismic events were dedicated to only three earthquakes (Fig. 3). The 
Table 1. Discourse content dictionary. Contains the keywords used to classify news items into categories of discourse corresponding to the main phases and topics of disaster risk management. Keywords were identified from a list of most frequent words using different thresholds for English (EN), Spanish (SP) and French (FR) to balance differences in the RSS feed numbers.

\begin{tabular}{|c|c|}
\hline $\begin{array}{l}\text { Content } \\
\text { categories }\end{array}$ & Keywords by themes and topics \\
\hline \multirow[t]{8}{*}{ Hazards } & Magnitude \\
\hline & $\begin{array}{l}\text { EN: magnitude, Richter } \\
\text { SP: grados, Richter, magnitud(es) } \\
\text { FR: magnitude, Richter }\end{array}$ \\
\hline & Tsunami \\
\hline & $\begin{array}{l}\text { EN: tsunami(s) } \\
\text { SP: tsunami(s), maremoto(s), olas } \\
\text { FR: tsunami(s) }\end{array}$ \\
\hline & Aftershocks \\
\hline & $\begin{array}{l}\text { EN: aftershock(s) } \\
\text { SP: aftershock(s), réplica(s) } \\
\text { FR: aftershock(s), réplique(s) }\end{array}$ \\
\hline & Other secondary hazards \\
\hline & $\begin{array}{l}\text { EN: avalanche(s), landslide(s), flood(s)/flooding } \\
\text { SP: avalancha(s), deslizamiento(s), alud, inundacion(es) } \\
\text { FR: glissement(s) de terrain, avalanche(s) }\end{array}$ \\
\hline \multirow[t]{6}{*}{ Impacts } & Impacts - general \\
\hline & $\begin{array}{l}\text { EN: hit(s), struck, felt, shook, shak(e)(ing)(en), rocked, jolt(s)(ed), rattled, shattered, sway(ed), battered, suffered, } \\
\text { toppling, crushed, strike, stricken, impact } \\
\text { SP: impacto, estimacion(es), afectación, sacud(e)(ido)(ida)(idas)(ieron), golp(e)(eó)(ea), golpead(o)(os)(a)(as), } \\
\text { azotó, azotado, sentido, se sintió, afectó, sufrieron, arrasó, temblar, asoló, castigad(o)(a) } \\
\text { FR: frappé(e), touché(s), ressenti(e), ébranlé, secoué }\end{array}$ \\
\hline & Human impact \\
\hline & $\begin{array}{l}\text { Human impact-general } \\
\text { EN: fatalities, casualt(y)(ies), victim(s), affected, stranded } \\
\text { SP: balance, víctima(s), afectados, damnificados, recuento(s), saldo, contabilizado } \\
\text { FR: bilan, victime(s), sinistrés } \\
\text { Human impact - death toll } \\
\text { EN: death(s), kill(s)(ed)(ing), dead, bodies, died, deadly, claimed } \\
\text { SP: muerto(s), muerte(s), mueren, murieron, mortal(es), fallecido(s), fallecieron, cuerpos, cadavers, decesos, mató } \\
\text { FR: mort(s), tué(e)(s), corps, meurtrier } \\
\text { Human impact-injured } \\
\text { EN: injured, wounded } \\
\text { SP: heridos } \\
\text { FR: blesses }\end{array}$ \\
\hline & Material damage \\
\hline & $\begin{array}{l}\text { Material damage - general } \\
\text { EN: rubble, damage(d), collaps(e)(es)(ed) (ing), devastat(ed)(ion), destroy(ed)(ing), destruction, wreckage, debris, } \\
\text { ravaged, ruins/ruined } \\
\text { SP: daños, escombros, dañad(os)(as), destruid(o)(os)(as), perdidas, destrucción, ruinas, caíd(o)(a), destruyó, de- } \\
\text { strozadas, colapso, devastó, devastadas, derrumb(e)(es)(aron)(ado) } \\
\text { FR: dévast(é)(ée), décombres, dégâts, détruit/détruits, effondr(ée)(ées), destructions, gravats } \\
\text { Material damage - on buildings } \\
\text { EN: homes, building(s), houses, structure(s), property } \\
\text { SP: edificio(s), vivienda(s), edificaciones } \\
\text { FR: maisons, bâtiments } \\
\text { Material damage - to infrastructure } \\
\text { EN, FR: no recurrent keywords were found } \\
\text { SP: eléctricas, infraestructuras }\end{array}$ \\
\hline
\end{tabular}


Table 1. Continued.

\begin{tabular}{|c|c|}
\hline $\begin{array}{l}\text { Content } \\
\text { categories }\end{array}$ & Keywords by themes and topics \\
\hline \multirow{12}{*}{$\begin{array}{l}\text { Emergency } \\
\text { response }\end{array}$} & Tsunami warning \\
\hline & $\begin{array}{l}\text { EN: tsunami warning(s), alert(s) } \\
\text { SP: alerta de tsunami, alarma } \\
\text { FR: alerte }\end{array}$ \\
\hline & Evacuation \\
\hline & $\begin{array}{l}\text { EN: evacuat(e)(ed)(ion)(ions), evacuees } \\
\text { SP: evacuad(os)(as), evacuar, evacuación } \\
\text { FR: evacu(ees)(er)(ation) }\end{array}$ \\
\hline & Aid, search and rescue \\
\hline & $\begin{array}{l}\text { General } \\
\text { EN: effort(s), response, respond, operation(s), deployed, aid, rescu(e)(es)(ed)(ing), relief, help(ed)(ing), assist(ance), } \\
\text { helicopter(s), chopper, aircraft, support, send(s)(ing), save(d), distribut(ing)(ion), airlifted, dig(ging), dug, missing, } \\
\text { search(ing), alive, pulled, trapped, recovered + Table } 2 \text { "Rescuers" } \\
\text { SP: operación/operaciones, gestión, respuesta, solidaridad, crisis, apoy(o)(ar), ordenó, responder, envoi, enviado(s), } \\
\text { reacción, ayuda, ayudar, ayudas, ayudando, rescate, rescatar, rescatan, rescatado, helicóptero(s), asistencia, socorro, } \\
\text { attender, ofrece, aeronave, búsqued(a)(as) + Table } 2 \text { "Rescuers" } \\
\text { FR: operation(s), répondre, secours, aide, sauver, assistance, disparu, chiens, recherchés, sans nouvelles + Table } 2 \\
\text { "Rescuers" } \\
\text { Vital needs and supplies } \\
\text { EN: food, hungry, sanitation, water, drink(ing), fuel, blankets, gasoline, suppl(y)(ies), resources, basic, vital, lack of, } \\
\text { goods, need, needed, material, equipment } \\
\text { SP: agua, alimentos, alimentaria, necesidad(es), comida, suministro(s) } \\
\text { FR: de materiel, besoins }\end{array}$ \\
\hline & Medical care \\
\hline & $\begin{array}{l}\text { EN: hospital(s), medical, medicine(s), disease(s), health, outbreak, epidemic(s), treatment, patients } \\
\text { SP: hospital(es), médico(s), salud, medicinas, sanitarios } \\
\text { FR: no recurrent keywords were found }\end{array}$ \\
\hline & Displacement and temporary shelter \\
\hline & $\begin{array}{l}\text { EN: shelter(s), outdoors, sleep, sleeping, homeless, refuge, fled } \\
\text { SP: noche al raso, albergues, tiendas de campaña, desplazados, refugio(s) } \\
\text { FR: camps, fuir, dehors }\end{array}$ \\
\hline & Cremation \\
\hline & $\begin{array}{l}\text { EN, FR: no recurrent keywords were found } \\
\text { SP: funerarias }\end{array}$ \\
\hline \multirow{2}{*}{$\begin{array}{l}\text { Recovery, } \\
\text { rehabilitation } \\
\text { reconstruction } \\
\text { (preparedness) }\end{array}$} & Recovery/reconstruction \\
\hline & $\begin{array}{l}\text { EN: recover(y)(ing), return to, returned, reconstruction, rebuild(ing), reopen(s)(ed), normal } \\
\text { SP: desescombro, reconstrucción, reconstruir, normalidad } \\
\text { FR: reconstruction }\end{array}$ \\
\hline
\end{tabular}

No recurrent keywords were found that unambiguously refer to risk assessment, development and land use planning/adaptation and mitigation measures/education and information/preparedness, contingency planning, consolidate preparations for next disasters.

"Nepal quake" was exceptionally well covered, representing $59.7 \%$ of the news, and the earthquakes in Chile (Ilapel) and Afghanistan (Hindu Kush) collected $6.1 \%$ and $5.8 \%$ of the news, respectively. The other events of the year (some of which are visible as small peaks in the brown curve in Fig. 3) share the remaining $28.6 \%$ of the coverage.

The curves of coverage intensity exhibit a similar trend for all earthquakes: the initial peak is followed by an exponen- tial decrease. This signature has been proved as typical of the media coverage of dramatic events, characterized by an initial shock to public opinion (Boomgaarden and de Vreese, 2007). The amplitude of the initial peak is higher in the case of the "Nepal quake" than in the other cases. The duration of the coverage is also much longer with a second peak, corresponding to the aftershock on 12 May, triggering a new round of coverage. This may be explained by various fac- 
Table 2. Identity matrix. Contains the keywords used to quantify the presence/absence of different categories of stakeholders. Keywords were identified from a list of most frequent words using different thresholds for English (EN), Spanish (SP) and French (FR) to balance differences in the RSS feed numbers.

\begin{tabular}{|c|c|}
\hline $\begin{array}{l}\text { Content } \\
\text { categories }\end{array}$ & Keywords by themes and topics \\
\hline States & $\begin{array}{l}\text { EN: nation, state(s), government(s), authorities, minister(s), ministry, foreign secretary, foreign office, president, } \\
\text { parliament, royal rulers, embassy, European Union } \\
\text { SP: país, nación, gobierno, autoridades, ministerio, ministro, president(a)(e), exteriores, funcionarios, gabinete, } \\
\text { ispr, fata, europea } \\
\text { FR: pays, gouvernement, affaires etrangeres, autorités, ministère, ministre, Quai d'orsay }\end{array}$ \\
\hline UN agencies & $\begin{array}{l}\text { EN: United Nations, UNICEF, UNESCO, World Food Programme } \\
\text { SP: onu, naciones unidas, Programa Mundial de Alimentos, unesco, unicef } \\
\text { FR: nations unies, onu }\end{array}$ \\
\hline International aid & $\begin{array}{l}\text { EN: international aid, international agencies, aid agencies, humanitarian aid } \\
\text { SP: ayuda internacional, comunidad internacional, organización no gubernamental, ong, cruz roja } \\
\text { FR: aide internationale, croix rouge, humanitaire(s) }\end{array}$ \\
\hline $\begin{array}{l}\text { Civil security and } \\
\text { defense }\end{array}$ & $\begin{array}{l}\text { EN: police, army, military, marine(s), air force, soldiers, troops, firefighters, Gurkhas } \\
\text { SP: ejército, policía, militares, armada, marina, soldados, Oficina Nacional de Emergencia }\end{array}$ \\
\hline Rescuers & $\begin{array}{l}\text { EN: rescuers, rescue team(s), aid workers, rescue workers, relief workers, volunteer(s), personnel } \\
\text { SP: equipo de rescate, equipos de rescate, servicios de emergencia, rescatistas, socorristas } \\
\text { FR: équipe, secouristes, sauveteurs }\end{array}$ \\
\hline $\begin{array}{l}\text { Affected } \\
\text { people }\end{array}$ & $\begin{array}{l}\text { Those directly affected } \\
\text { EN: people, rescued, survivor(s), victims, those affected } \\
\text { SP: persona(s), víctima(s), los afectados, damnificados, desaparecid(o)(a)(os)(as), supervivientes, sobre- } \\
\text { vivient(e)(es), rescatad(o)(os) } \\
\text { FR: victimes, survivant(s), sinistrés, rescapes, personnes } \\
\text { Locals } \\
\text { EN: residents, locals, villagers, sherpa(s), guides, Famous locals: Ang Tshering, Bajracharya } \\
\text { SP: población, habitantes, guías } \\
\text { FR: habitants, villageois, population } \\
\text { Vulnerable people } \\
\text { EN: children, child, boy, girl(s), wo(man)(men), famil(y)(ies), teenag(e)(er), teen, bab(y)(ies) } \\
\text { SP: niños, famili(a)(as), muj(er)(eres), jóven, bebe, anciano } \\
\text { FR: familles, adolescent, enfants, orphelins }\end{array}$ \\
\hline "Experts" & $\begin{array}{l}\text { EN: expert(s), US Geological Survey, specialists, scientists } \\
\text { SP: usgs, Centro Sismológico Nacional, especialistas, Servicio Hidrográfico y Oceanográfico de la Armada } \\
\text { FR: usgs, institute américain de géophysique }\end{array}$ \\
\hline $\begin{array}{l}\text { Private } \\
\text { companies }\end{array}$ & $\begin{array}{l}\text { EN: Google, Facebook, compan(y)(ies) } \\
\text { SP: Google, Facebook } \\
\text { FR: no recurrent keywords were found }\end{array}$ \\
\hline
\end{tabular}

tors, including a death toll an order of magnitude higher and that it affected the economic and political center of a touristic country (Koopmans and Vliegenthart, 2010). However, despite these differences in intensity and duration, the overall signature of the "Nepal quake" is similar to the signature of the Hindu Kush earthquake, likely because both events occurred in similar geodynamical settings (i.e., intracontinental faulting) and both caused massive impacts (i.e., huge death tolls and vast material damage). The real question is why the Chilean earthquake, which only caused moderate impacts, was so well covered. Occurring in a different geodynamical setting (i.e., subduction faulting), the earthquake triggered tsunami waves threatening many countries on the ocean rim. The release of the tsunami alert explains the level of the international coverage in remote countries. All together, these observations support earlier works showing that the death toll in itself is not sufficient to predict the volume of media coverage, as other factors - such as the physical, political or economic distance to the place of publication - also influence the newsworthiness of disasters (i.e., Adams, 1986; Simon, 1997; and Van Belle, 2000, among others). 


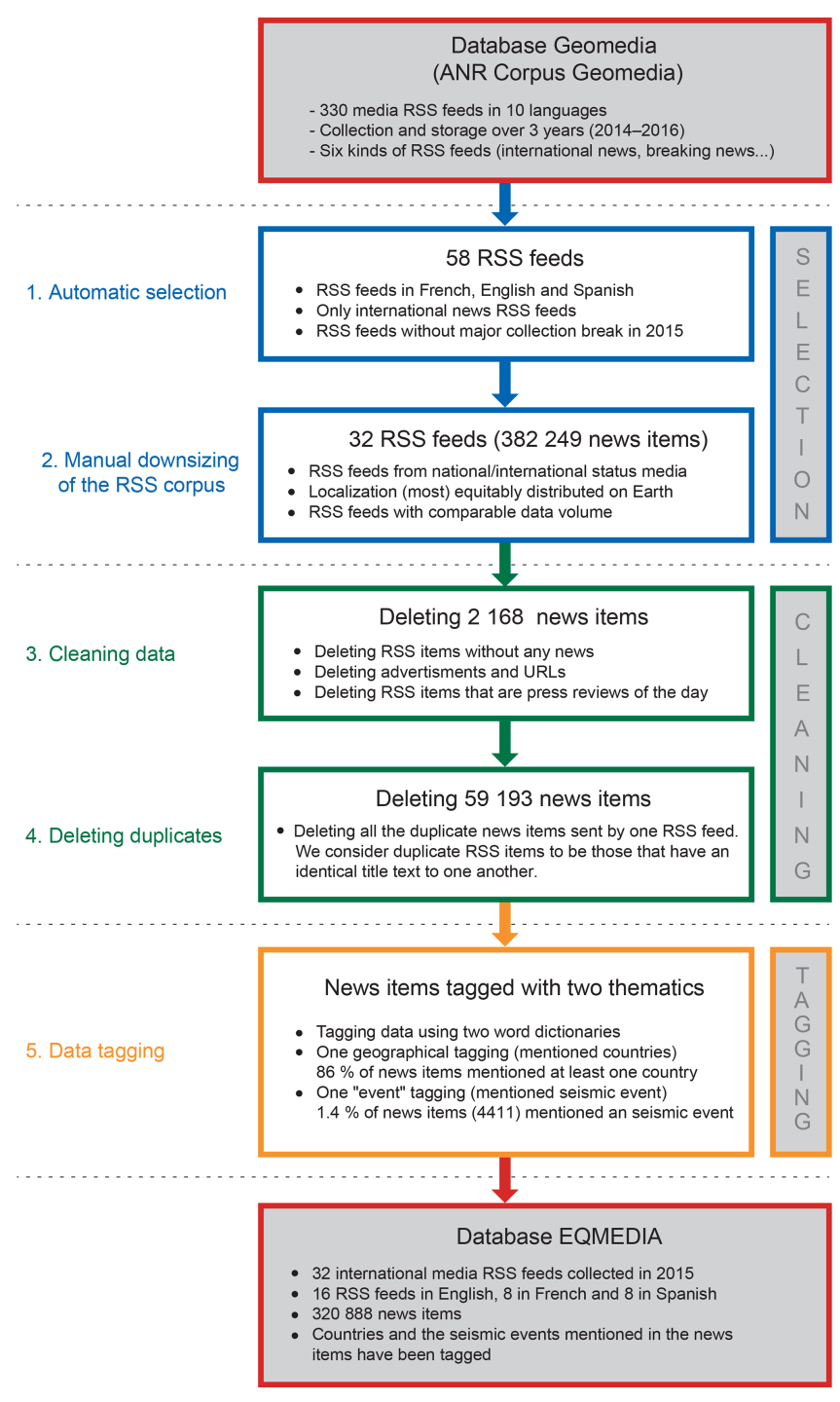

Figure 2. Building the EQMEDIA database.

Generally, the main peaks of intensity are not significantly different among the English, Spanish and French newspapers. Only small differences are observed, essentially in the extent of the main peaks or in the secondary peaks. The similarity of the results obtained in the three different languages confirms the robustness of our methodology. It also suggests the existence of a typical - and global - framing of the "earthquake news", inviting us to dive deeper into the analysis of content.

\section{2 "Earthquake news" analysis of content}

\subsubsection{News reproduces the categories of content expected from disaster risk management (DRM) models}

The "earthquake news" content broadly reproduces the sequence expected from DRM models but with an important bias: the duration of coverage is too short (hours to days) for mid- to long-term issues (weeks to months or years) to be well covered (Fig. 4). The themes of hazards, impacts and emergency response are overrepresented compared with those of recovery, restoration, reconstruction and preparedness:

- $77 \%$ of the news items contain a general description of the impacts of the event, either simply to outline its level of destructivity or to count fatalities;

- $46 \%$ of the news items refer to the hazards, often to communicate the magnitude of the earthquake but sometimes to inform about secondary hazards such as tsunamis, aftershocks and, more rarely, avalanches, mud slides or floods;

- $45 \%$ of the news items refer to emergency response describing either aid or search and rescue operations (in the case of the Nepal and Hindu Kush earthquakes) or the release and lifting of tsunami warnings (in the case of the Ilapel earthquake);

- and only $5.6 \%$ of the news items refer unambiguously to recovery, restoration and reconstruction, while none refer directly to issues of preparedness. These low percentages are partially due to the small numbers of keywords identified for each of these themes, but it is the low frequency of these themes in the database that prevented us from identifying more keywords.

It is interesting to note that the big aftershock on 12 May in Nepal triggered a new cycle of information. Although characterized by a peak of smaller intensity, the news content followed a similar sequence to that triggered by the main shock.

Figure 5 shows the temporal distributions of these themes. The Nepali and the Afghan earthquakes have similar signatures: content on hazards comes first, followed soon after by content on impacts; content on response comes next; and content on recovery, rehabilitation and reconstruction comes later - when it comes at all. The Chilean earthquake has a significantly different signature, which is due to its tsunamigenic character. The news focuses first on the hazards including tsunamis, which means that the content on the response (tsunami warnings) appear much earlier.

\subsubsection{The typical "earthquake news"}

To give a sense of the framing of "earthquake news", in the following, we build an (artificial but well-informed) example of the evolution of the news content over time after an event. Of course, there are variations due to elements of context, but our guess is that the main trends would remain comparable. 


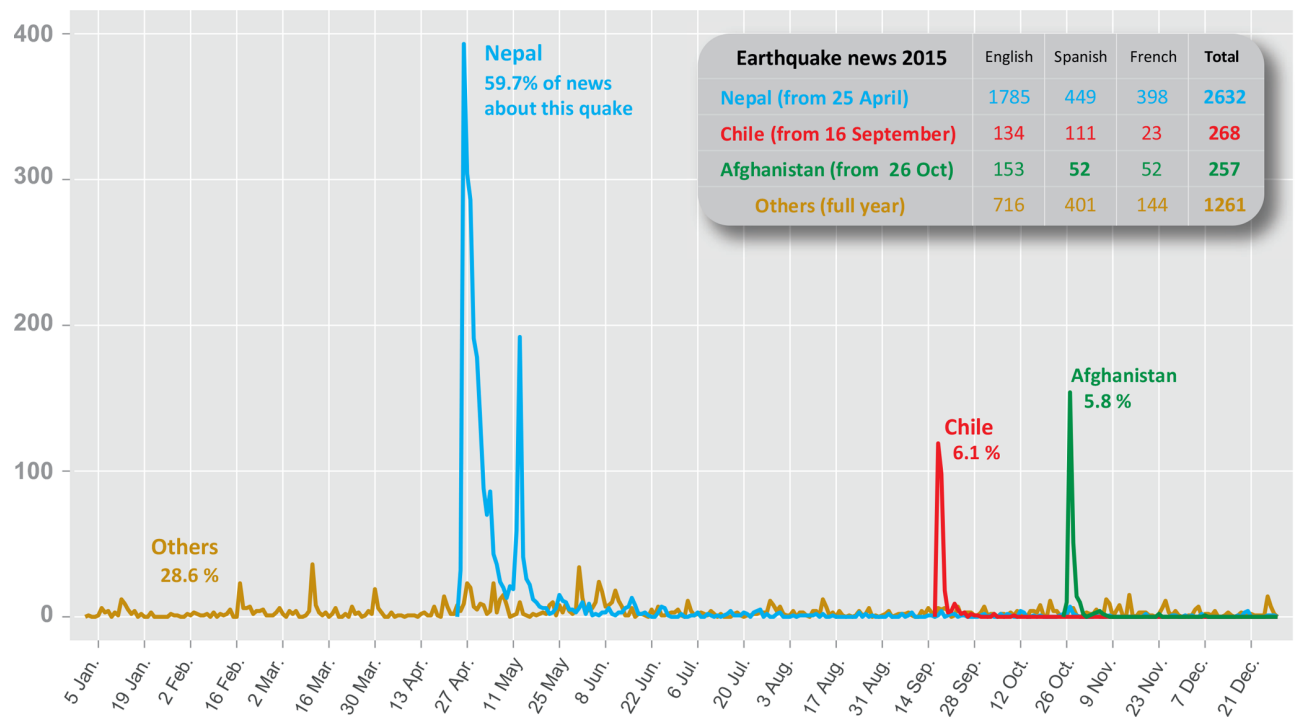

Figure 3. The media coverage intensity (number of news items published per day) for the year 2015 is dominated by three events: the Nepal quake, an earthquake in the area of Ilapel, Chile, and an earthquake in the Hindu Kush region, Afghanistan.

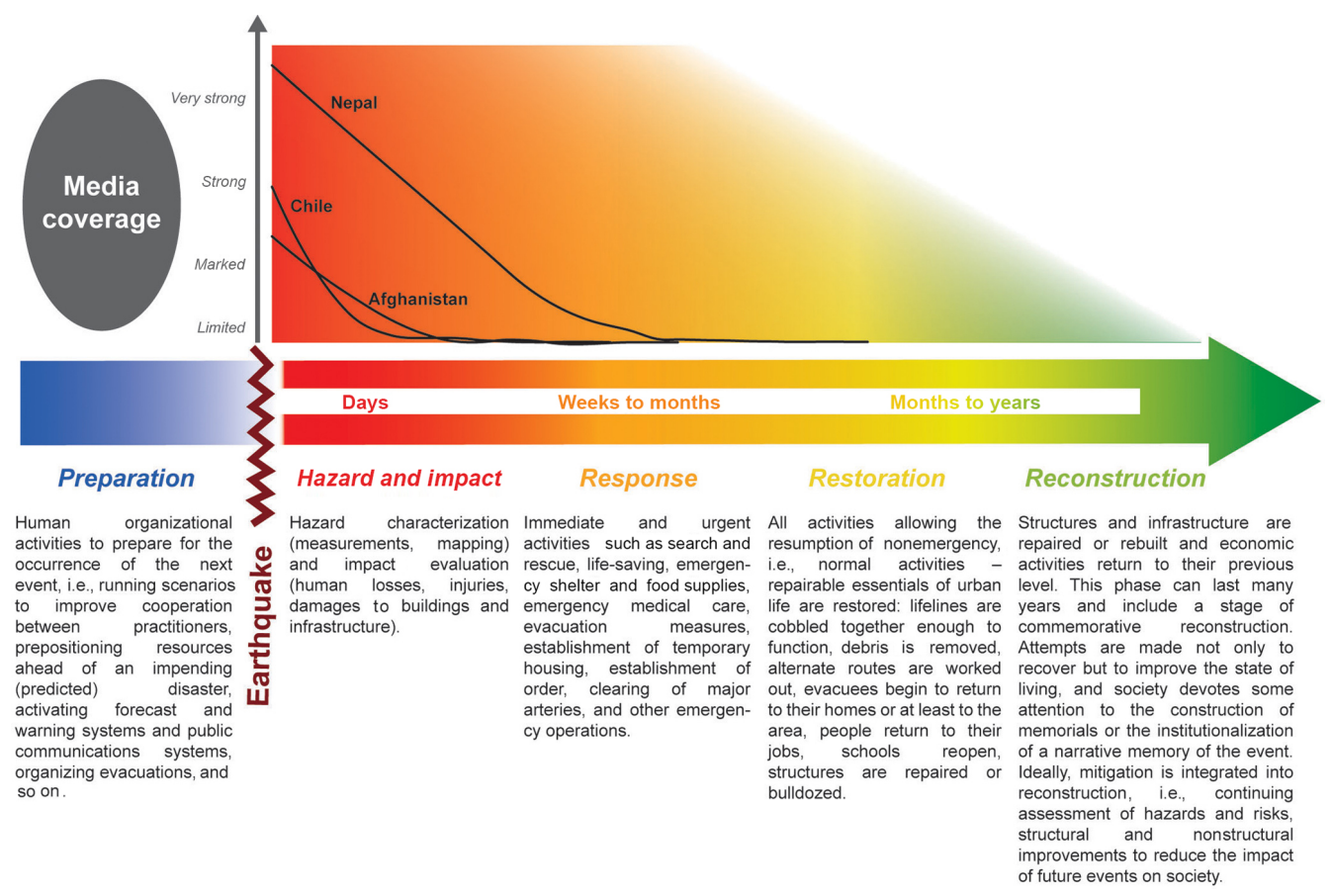

Figure 4. Temporal distribution of the media coverage for the three well-covered earthquakes of the year 2015. The color scale allows for comparison of the duration of the media coverage with the expected duration of the different phases of disaster risk management models.

Imagine that an important earthquake occurs. . .

\section{- Within a few hours}

The news focuses on the description of the seismic hazard and, when relevant, passes on information about tsunami warnings. The news first reports that an earthquake has been felt, providing the approximate location of the impacted area (often a country, some- times a region or a city). Many recall the magnitude of the event, e.g., "USGS: Magnitude 7.5 earthquake strikes Afghanistan" (USA today, 26 October, item 10366718), "Un terremoto de 7.9 grados sacude el centro de Nepal"" (Faro de Vigo, 25 April, item 6369528) and "Un séisme de magnitude 7.5 a secoué lundi le mas-

\footnotetext{
1 "7.9 magnitude earthquake rocks central Nepal”
} 
Table 3. Percentage of news items mentioning a theme or topic. NB: one news item can include several themes and topics.

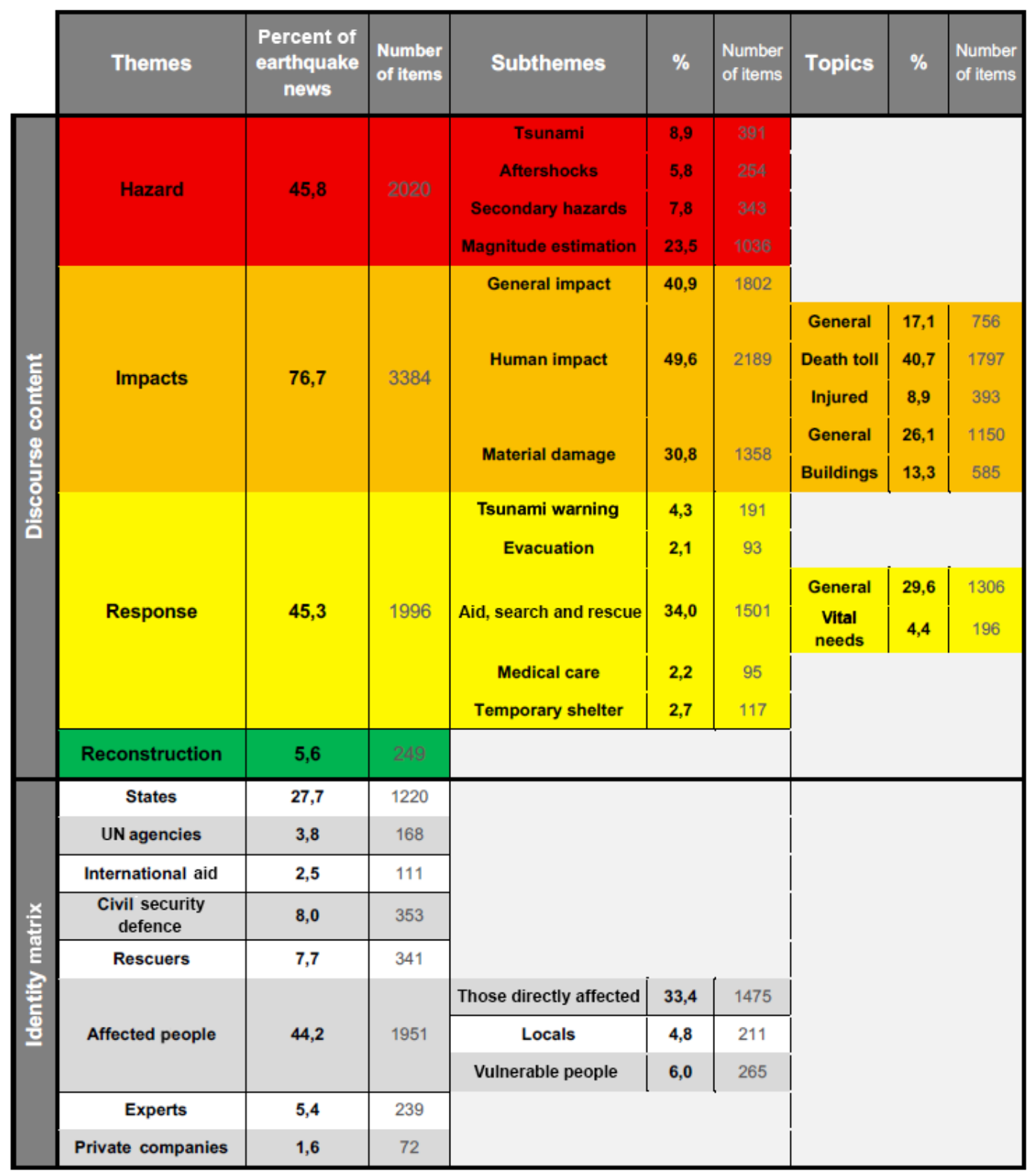

Corpus $=320888$ news items, including 4411 news items about earthquake $(1,37 \%)$

sif de l'Hindu Kush"' (Le Monde, 26 October, item 10368842).

It quickly becomes clear that the event is worth mentioning because it had noticeable impacts, e.g., "La ONU advierte dramático impacto tras nuevo temblor en Nepal"3 (El informador, 13 May, item 6774985) and "Scores of people were killed when a 7.5-magnitude

2“A 7.5 magnitude earthquake shook the Hindu Kush massif on Monday"

3"UN warns of dramatic impact after new earthquake in Nepal" earthquake centered in Afghanistan rocked neighboring Pakistan and rattled buildings as far away as India." (USA Today, 26 October, item 10371195).

The combination of the location and magnitude is often use to "label" the event and distinguish it from other such events. After a few days, "big" events are known by their "nicknames", and the magnitude is mentioned less often. A few hours after the main shock, journalists named the earthquake in Nepal the "Nepal earthquake", and it soon became the "Nepal quake", e.g., "5 things to know about the Nepal earthquake" (The Star, 25 April, 

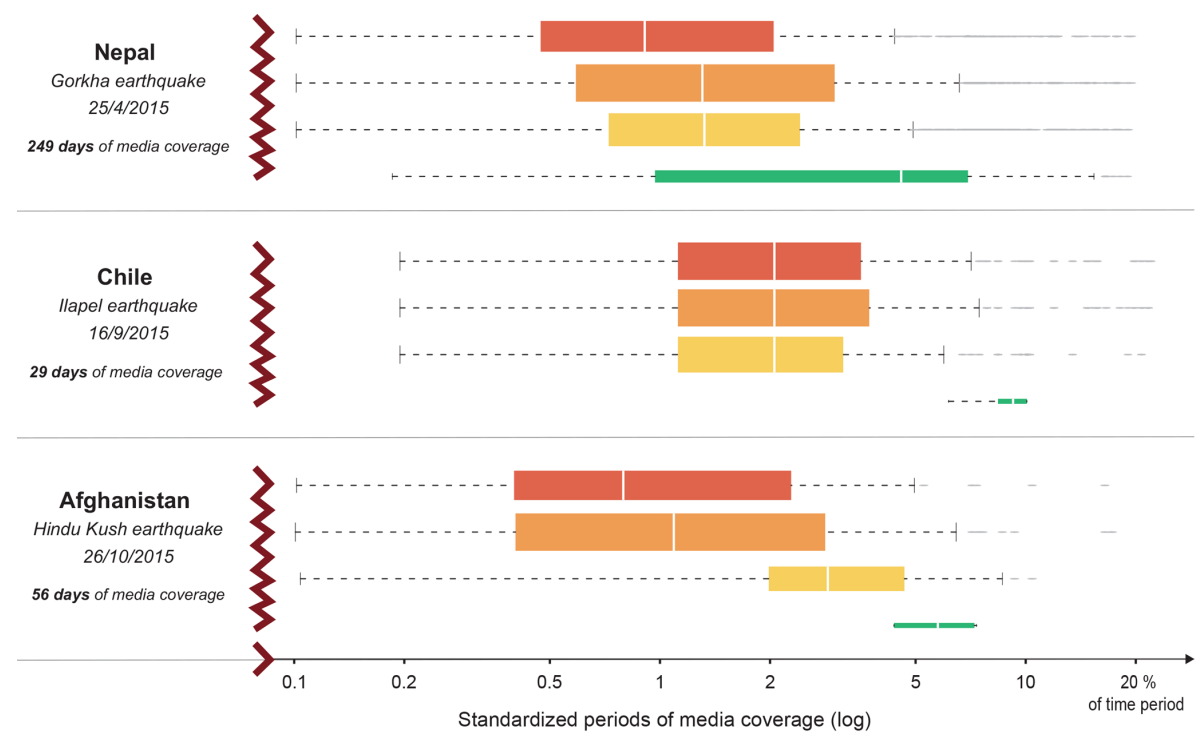

Hazard

Figure 5. Temporal distribution of the DRM categories in the media coverage of the three main earthquakes in 2015. The height of the boxes is proportional to the number of news items (for each earthquake). The beginnings and ends of the boxes correspond to the first and third quartiles, respectively. The white lines inside the boxes correspond to the median values.

item 6376436) and "Nepal quake: 7.9 magnitude tremor hits near Kathmandu" (The Guardian, 25 April, item 6370804). However, only a few earthquakes become famous enough to be called by nicknames; the Chilean and Afghan earthquakes of 2015 did not, and the news settled for recalling the country and magnitude of the main shocks.

Interestingly, the initial phase of coverage is also the phase with the most scientific content. The extensive use of the notion of magnitude, although often made at the expense of the notion of seismic intensity, testifies to the successful transfer of a geophysical notion to the general public. We should also outline here that aftershocks are sometimes treated as singular events by the press, with the notion of a seismic crisis remaining unclear to many. Among the most cited expert bodies, the USGS is the most visible internationally, as it provides immediate information about the earthquakes. Regionally important centers such as national meteorological agencies and emergency operations centers, among others, can also be cited.

Secondary hazards are barely mentioned in the news, except for tsunamis. In Chile, the news conveyed the information about tsunami warnings very well, mentioning the primary and the secondary hazards and the authorities' response to it at the same time, e.g., "Tsunami warnings in Chile and Peru as 8.3 quake hits" (Daily Telegraph, 17 September, item 9501990) and "The tsunami warning from New Zealand's Min- istry of Civil Defence \& Emergency Management after a big quake off Chile will affect a night surfing event." (The Age, 17 September, item 9504366).

\section{- A few hours to few days after the event}

The peak of coverage is reached within a few hours to a day after the event, with many updates of the same news including more and more precision or detail. Earthquake events become "breaking news" or "top stories" and are simultaneously disseminated on different RSS feeds. Most news talks about impacts, especially human losses. The description of the impacts is the theme that attracts the most coverage: $76.7 \%$ of the news of our corpus focuses on the description of the impacts ( $81 \%$ for the three considered earthquakes), $34.3 \%$ focus on human losses and only $17.3 \%$ on material damage. Messages about human impacts adopt a factual tone and evolve following a rather systematic pattern.

For illustration, we provide an example of the treatment by The Guardian of the "Nepal quake". The news starts by mentioning the occurrence of an event with fatalities, e.g., "Fatalities as earthquake hits Nepal" (The Daily Telegraph, 25 April, 09:19, item 6371294). Within a few hours, the regular update of the human losses starts, e.g., "Nepal earthquake: more than a hundred people dead" (The Guardian, 25 April, 12:04, item 6371816), "Nepal earthquake: nearly 700 people dead" (The Guardian, 25 April, 13:42, item 6373501) and "Nepal quake: more than 1,000 people dead after tremor near Kathmandu" 
(The Guardian, 25 April, 17:44, item 6381853). As the hours go by and the numbers continue to rise, concurrent topics begin to emerge, stories become more personalized and the news starts referring to distinct categories of victims (famous people, nationals, vulnerable people and so on), e.g., "Nepal quake kills more than 1,000 and spreads terror on Everest" (The Guardian, 26 April, 00:23, item 6382569), "Google executive Dan Fredinburg filmed at Everest base camp before death" (The Guardian, 26 April, 16:49, item 6396313) and "Népal: le bilan des victimes françaises pourrait s'alourdir"4 (Le Parisien, 3 May, item 6542461). Aid and rescue operations and life conditions start attracting interest, e.g., "Nepal earthquake: rescue continues as death toll exceeds 2,500" (The Guardian, 26 April, 18:18, item 6397229) and "Nepal earthquake: thousands seek shelter as death toll exceeds 2,500" (The Guardian, 27 April, 02:04, item 6402976). As the days go by, the death toll appears less frequently, with the news reporting official numbers only when those are updated, e.g., "Nepal earthquake death toll exceeds 4,000 with many still missing. More than 4,000 are confirmed dead and 6,500 injured..." (The Guardian, 28 April, item 6430398). Proportionally, there is a lack of interest in injuries and general health issues (with psychological issues even more strongly ignored).

During the phase of coverage dedicated to impacts, we observe a tendency toward sensationalism. Almost half of the news items use adjectives such as "devastating", "powerful", "catastrophic", "enormous", "dramatic", "monster" or "violent", emphasizing the extent of the devastation. Surprisingly, terms referring directly to emotions (such as "fear", "desperation", "panic" and "courage" among others) remain rare. For example, "Nepal's second monster quake" (The Australian, 12 May, item 6749166), "As rescue efforts were hampered by bad weather, dramatic details emerged about the devastation at the base camp in the wake of an avalanche" (The New York Times, 28 April, item 6423784), "Nepalíes cavaron con sus manos para sacar a sobrevivientes de montañas de escombros. Pánico. Lágrimas. Miedo. Todos estos sentimientos se conjugaron ayer como parte de la jornada trágica que vivieron los miles de nepalíes que habitan Katmandú, y es que tras el fuerte terremoto de 7.8 grados en la escala de Richter que dejó en el país al menos mil 475 muertos [...] los sitios históricos están completamente devastados"5 (La

\footnotetext{
4"Nepal: the death toll in France could increase"

5 "Nepalese dug with their hands to remove 25 survivors from mountains of debris. Panic. Tears. Fear. All these feelings were experienced yesterday as part of a tragic day for the thousands of Nepalese living in Kathmandu, as a strong earthquake of 7.8 degrees on the Richter scale left at least 1475 dead [...] the historical sites are completely devastated."
}

chronica de hoy, 26 April, item 6387254), "vías de comunicación completamente sepultadas por corrimientos de tierra y rocas"6 (La chronica de hoy, 27 October, item 10394058), "En el barrio de Gongabu, completamente arrasado, fallecieron 500 de las 8.000 víctimas del terremoto"7 (El Pais, 13 May, item 6779435) and "Reportage dans des villages coupés du monde, dévastés par la catastrophe, où les secours peinent à arriver comme l'aide des autorités." 8 (Le Monde, 28 April, item 6434796).

\section{- Within a few days following the event}

The focus slides from impacts to response operations. A total of $45.2 \%$ of the news of our corpus refers to this category (Table 3 ). In the case of a tsunami alert, the theme of response operations appears earlier in the coverage, as the news passes on information about warnings and, if relevant, mass evacuations. In the absence of a tsunami threat, the news focuses on aid and search and rescue operations, e.g., "Rescue teams dig for Nepal quake survivors" (USA Today, 27 April, 6401498), "Rescuers were struggling to reach quake-stricken regions in Pakistan and Afghanistan on Tuesday as officials said the combined death toll from the previous day's earthquake rose to 339." (The Times of India, 27 October, item 10393016) and "FRANTIC rescue efforts to save people trapped under rubble are taking place after a 7.9 magnitude earthquake hit near Nepal's capital, Kathmandu." (Daily Telegraph, 25 April, item 6372184). In these cases, evacuation and displacement are generally under-reported.

First, the messages adopt a general tone, becoming more specific when the international community starts sending help, e.g., "China's rescue team pulls first survivor out of debris after Nepal quake" (China Daily, 27 April, item 6409965), "The burly Californian and fellow members of a disaster response team deployed by the U.S. Agency for International Development were looking, against all odds, for collapsed buildings that might still have people trapped alive[... ]" (The Los Angeles Time, 1 May, item 6499637) and "Turkish rescue workers in Kathmandu, Nepal pulled a man alive from the rubble of a destroyed building on Monday." (USA Today, 27 April, item 6414192).

We note the tendency of the international news to glorify the contribution of the international community to

\footnotetext{
6"Communication routes completely buried by landslides of earth and rocks"

7 “The neighborhood of Gongabu - completely wiped out - 500 of the 8000 people died in the earthquake"

8 "Report from villages cut off from the world: devastated by the disaster, with relief efforts as well as help from authorities are struggling to arrive"
} 
help the "poor and vulnerable", e.g. "As world leaders and global charities tried to grasp the scope of an earthquake that devastated Nepal, they offered condolences for the nearly 1,400 people killed and readied emergency aid for the survivors. Mountaineering groups struggled to check on climbers, and Nepalese abroad did their best to reach families in the stricken area." (The Times of India, 26 April, item 6382872) and "With the help of Los Angeles firefighters, rescuers Thursday pulled a teenage boy from the wreckage of a nine-story Katmandu hotel that collapsed around him five days ago when an enormous earthquake shook Nepal." (The Los Angeles Times, 30 April, item 6494627).

Rescue operations are also an occasion for relating personal stories, if not miraculous ones, e.g., "Google executive Dan Fredinburg filmed at Everest base camp before death" (The Guardian, 26 April, item 6396313) and "Boy found alive 5 days after Nepal quake" (The Age, 30 April, item 6481498). Such stories can take different forms depending on context. In Nepal, one finds several stories about "children saved from the rubble" (The Guardian, 30 April, item 6480552). In Afghanistan, stories focus on "twelve girls caught in a stampede while trying to escape from their school" (Daily Telegraph, 26 October, item 10367166).

At this stage, the duration of coverage plays an important role in the richness of the content of the news. The coverage of the "Nepal quake" is longer and richer: the living conditions, internal displacement, epidemic risk and mass cremation are all issues that are not at all addressed in the coverage of the other earthquakes.

\section{- A few days to few months after the event}

The coverage intensity has faded out, impeding the proper coverage of long-term issues (Fig. 4). Few news items refer to recovery, which tends to cover distinct temporalities, from a few days to several months (Table 3), e.g., "Nepalese villagers clean up four days after a monster earthquake killed more than 5,000 people in the Himalayan nation" (USA today, 29 April, item 6462063) and "The International Federation of Red Cross and Red Crescent Societies warned on Friday that longer-term support is needed to help shattered communities recover six months after a magnitude 7.8 earthquake struck Nepal." (China Daily, 10 October, item 10361489)

The theme of reconstruction is dedicated to more permanent repairs and rebuilding. There are enough news items referring to this theme for us to identify a few keywords, but the coverage remains poor (Table 3 ). There are again different temporalities. In the short term, the news reports that people are rebuilding their homes. In the longer term, the news reports the reopening of public infrastructure such as schools, hospitals and histori- cal buildings as a sign of returning to normal life, e.g., "Survivors in quake-hit Pakistan seek help to rebuild homes" (Times of Malta, 28 October, item 10408082) and "Hundreds of thousands of Nepalese children have returned to school in Nepal for the first time since two earthquakes last month killed more than 8,700 people and injured 23,000..." (The Guardian, 31 May, item 7161853)

\section{- A window of communication for scientists}

According to Haas et al. (1977), the second and longer phase of reconstruction corresponds to the continuing assessment of hazards and risks and structural and nonstructural improvements to reduce the impact of future events (i.e., mitigation and adaptation measures as well as prevention). This phase lasts many years, during which attempts are made not only to recover but to improve the state of living, and society devotes some attention to the construction of memorials or the institutionalization of a narrative memory of the event. We could not find enough news items referring to mitigation, adaptation and prevention to identify keywords. There are, however, a few items referring to a narrative dimension: the ones that place the event in a country's history. For example, "El terremoto fue el sexto mayor movimiento telúrico en la historia de Chile y el de mayor intensidad en el mundo durante 2015." " (El Universal, 17 September, item 9516610).

A few news items also mention the lessons learned (or not learned) from past events, e.g., "Nepal earthquake: learn lessons or more will die in future disasters, warns expert" (The Guardian, 29 April, item 6460947) and "How Nepal can avoid the mistakes of Haiti" (The Guardian, 12 May, item 6745299).

By doing so, the press contributes to maintaining a form of knowledge about existing risks. This contribution to the collective memory often happen just after the main shock (or after large aftershocks). It is also a time when the press listens to experts, and so it might be a good window for communication. People are looking for elements to make sense of what has just been going on. This time window could be used to reinforce preparedness in the general population, as news about a disastrous earthquake - even located far away - may momentarily alter the feeling of safety among readers (Wood et al., 2012).

\subsubsection{The figures of "earthquake news"}

The identity matrix allows for the identification of the categories of actors that are the most present in the news. A total of $44.2 \%$ of the news mentions the people affected by the

\footnotetext{
9،"The earthquake was the sixth largest telluric movement in Chile's history and the most intense in the world in 2015"
} 
earthquake. The exact terminology varies with time: "those affected" start as "victims" to become "rescued", "survivors" and then "locals" or "villagers". A total of $6 \%$ of the news refers explicitly to vulnerable people.

A total of $27.7 \%$ of the news mentions state representatives who are responsible for organizing the public response, but regional and local public services are absent (Table 3). Surprisingly, only $8 \%$ of the news refers to civil and military security services and $7.7 \%$ to rescuers in general. Only $3.8 \%$ of news sources mentions UN agencies; $2.5 \%$ refer to international aid; and $5.4 \%$ refer to experts, specialists or scientists, mostly during the initial phase of coverage after the main shock and after the big aftershock in the case of the Nepal quake. The private sector is rarely mentioned, except Google and Facebook due to their people finder tools. Other figures emerging from the "earthquake news" are "famous unknowns" whose stories serve to exemplify the experience of the people affected. The news sometimes refers to famous personalities, either because they are among the victims or due to their generous donations. It is interesting to observe that local communities and their representatives are almost absent from the news. This confirms one classical rule of newsworthiness regarding the preference for elite people and celebrities (Galtung and Rudge, 1965; Harcup and O'Neill, 2001, 2017).

\section{Discussion}

Studying earthquake coverage at the global scale, we reach different conclusions to authors such as Rovai and Rodrigue (1998). Among the 7136 earthquakes of magnitude $4.5+$ occurring in 2015 , we indeed observe significant differences in coverage: most events are not reported by the news media, except a few that are particularly well covered. However, once events are covered, we observe an astonishing homogeneity in the news content. There are, of course, variations in the way journalists treat the information - editorial choices and cultural proximity to the impacted countries are both parameters influencing the duration and content of the coverage - but these variations remain small. Our results suggest that there is a typical framing of the earthquake in the international news.

This framing seems to introduce major biases in the representation of the seismic risk. A first bias is linked to the short duration of the coverage. Analyzing Google Trends, Tan and Maharjan (2018) confirm our empirical observation that the peak in public interest after destructive earthquakes follows an exponential temporal decay. The same tendency was observed for smaller events by Earle et al. (2010). Our results complement these findings, showing that the international online journals follow the same tendency. However, we go further than previous studies in exploring the consequences of that exponential decay on the news content. It focuses the information on short-term issues such as the description of the hazard and of its impacts and emergency operations. The mid-term and long-term issues of recovery, restoration, reconstruction, adaptation, mitigation and preparedness are largely under-reported.

This finding outlines the necessity for scientists to communicate, whenever possible, within a few hours following the occurrence of an earthquake, especially big events that are the most capable of catching a large audience. Of course, the need for reactive communication should not result in unpreparedness. Having a knowledge of the content and the evolution of typical earthquake news can help design typical communication tools that could be quickly adapted on a case by case basis once an event has occurred. Designing scientific messages, one should pay particular attention to counterbalance the known biases.

Communicating about the hazards, for instance, it would be important not to insist on including information about the magnitude but to find simple words to pass on the notions of seismic intensity and seismic crisis. As discussed in a previous paper (Le Texier et al., 2016), the term of magnitude is commonly used as a synonym for intensity by the news media. However, the notion of intensity is the only one that allows for the introduction of the notion of differential damages, which is required to understand the importance of mitigation and preparedness (earthquake-resistant construction, site effects and so on). Another topic that is absent from news media narratives is that of the location of the next event. Coulomb stress triggering theory can help answer that question, at least probabilistically speaking. Thus, it could be interesting to communicate on the dynamics of the seismic phenomenon, notably to help design adequate prevention measures (it might shake elsewhere the next time! It might shake again several times after the main shock!). Regarding impacts, our analysis supports the statement from McClure et al. (2001) that the representation of the seismic risk that is built by the press emphasizes the immediate and overly destructive nature of the event, occulting the real timing of such disasters: a time to anticipate and get prepared, a time to protect, and a time to recover and reconstruct. We agree with authors such as Lamontagne et al. (2016) and Wood et al. (2009), who stated that scientific messages should encourage people to take preparatory actions and get them prepared for potential losses, describe to them the timeline of the disaster cycle and teach them ways to diminish losses.

Although unprecedented, we are aware that our study also has some caveats. The use of keywords to quantify themes and topics provides robust conclusions but is not completely satisfactory. We tried to get around these limitations by preselecting words from a list of the most frequently used terms. A further step is to engage with more complete techniques of text analysis, combining inductive and deductive approaches. We could, for example, use machine learning methods such as word2vec (Le and Mikolov, 2014) for the simplification of the collection of keywords and the quantification of the different steps of the news coverage. However, this tool would 
complement but not replace the qualitative analysis of the content we undertook in this study.

One of our working hypotheses was to demonstrate the existence of a global framing of earthquake news. To reach this goal, we chose to work on the international news, but it would be important to undertake a similar analysis on the national and regional press as well as social media. A recent work by Jamieson and Van Belle (2019) suggested, for instance, that the level of development of the disaster-stricken community influences the nature of news coverage in other at-risk communities: "if an earthquake occurs in a community with a high level of development, the news coverage is much more likely to draw lessons for their community, and less likely to emphasize differences that prevent policy learning".

Another interesting lead to explore would be to study the evolution of the public state of mind as they read the news. This could allow for more careful selection of the information to provide and when to provide it (see Wein et al., 2016, for an example).

\section{Conclusion}

"Most people do not experience disasters first-hand, but rely on mediated depictions of distant events." (Jamieson and Van Belle, 2019). This is why it is of utmost importance to study the narratives built by the news media when reporting about distant disasters. In this paper, we explore the news media coverage of seismic events in the international news during the year 2015, analyzing 320888 news items published in English, Spanish or French by 32 RSS feeds distributed worldwide. Among the 7136 earthquakes of magnitude 4.5+ occurring that year, three were predominantly covered: the sadly famous "Nepal quake" that hit the valley of Kathmandu in April, an earthquake in Chile that shook the area of Ilapel in September and an earthquake in Afghanistan that struck the Hindu Kush in October. We compare the duration and content of the news media coverage of these three major earthquakes with classical models of disaster risk management.

In doing so, we demonstrate (1) that there is a typical framing of the news regarding earthquakes in the international news, and (2) that this framing introduces major biases in representation, impeding the proper appropriation of the seismic risk by the public. The news content faithfully follows the succession of phases predicted by the DRM scheme, describing the hazard before reporting on its effects and the response of the communities impacted. However, an important bias is introduced by the very short duration of coverage: only the first phases of the DRM scheme are covered, whereas the issues of recovery, restoration, reconstruction, adaptation, mitigation and preparedness remain largely ignored. We also observed the following biases: (i) the news tends to concentrate on the description of im- pacts and, among them, more specifically on human losses. This focus is associated with the pervasive use of sensationalistic terms describing a landscape of devastation, which may contribute to fatalistic judgments that the damage cannot be prevented. (ii) The second theme of interest - the second in terms of coverage intensity but the first in terms of timing is that of hazards. The communication is centered on the notion of magnitude, with the concept of seismic intensity being ignored. Aftershocks can occasionally be treated as isolated events, testifying to a lack of understanding of the concept of the seismic crisis and, except for tsunamis, secondary hazards are barely mentioned. (iii) The third theme of interest is that of the emergency response. The focus is on alerts and evacuations in the case of tsunami warnings and on aid, and search and rescue otherwise. Other issues such as safety measures, temporary housing, water or electricity cuts and so on, as well as longer-term issues are barely mentioned.

On the basis of that analysis, we discussed leads to improve the scientific communication on earthquakes. Taking advantage of the short window of interest that follows big earthquakes, scientists should familiarize people with the real timeline of a seismic disaster cycle... which tends to last longer than the interest of the news media.

Data availability. This paper benefited from the GEOMEDIA database produced and maintained by the International College of Territorial Science (http://www.gis-cist.fr, last access: 1 November 2018). Earthquake parameters were obtained from the USGS Comprehensive Earthquake Catalog (ComCat), which was searched using https://earthquake.usgs.gov/earthquakes/search/ (last access: 1 November 2018).

Author contributions. MHD was responsible for the conceptualization of the study, project administration, methodology and writing the original draft of the paper, as well as the writing, revision and editing the final paper in concert with all co-authors. MHD, MLT and HP were responsible for data curation and investigation. MLT and HP undertook the formal analysis. MLT and MHD carried out the validation. HP and MHD were responsible for the figures, and MHD created the tables. CG provided access to the GEOMEDIA database.

Competing interests. The authors declare that they have no conflict of interest.

Financial support. This research has been supported by the Université de Paris, Centre des Politiques de la Terre. It is IPGP contribution number 4031 .

Review statement. This paper was edited by Jon Tennant and reviewed by Lisa Matthias and Iain Stewart. 


\section{References}

Adams, W. C.: Whose lives count? TV coverage of natural disasters, J. Commun., 36, 113-122, 1986.

Blei, D. M., Ng, A. Y., and Jordan, M. I.: Latent dirichlet allocation, J. Mach. Learn. Res., 3, 993-1022, 2003.

Boin, A., McConnell, A., and Hart, P. T. (Eds.): Governing after crisis: The politics of investigation, accountability and learning, Cambridge University Press, New York, USA, 2008.

Boomgaarden, H. G. and de Vreese, C. H. Dramatic real-world events and public opinion dynamics: Media coverage and its impact on public reactions to an assassination, Int. J. Public Opin. R., 19, 354-366, 2007.

Church, K. W. and Hanks, P.: Word association norms, mutual information, and lexicography, Comput. Linguist., 16, 22-29, 1990.

Cocco, M., Cultrera, G., Amato, A., Braun, T., Cerase, A., Margheriti, L., Bonaccorso, A., Demartin, M., De Martini, P. M., Galadini, F., Meletti, C., Nostro, C., Pacor, F., Pantosti, D., Pondrelli, S., Quareni, F., and Todesco, M.: The L'Aquila trial, Geol. Soc. Spec. Publ., 419, 43-55, 2015.

Cottle, S.: Rethinking media and disasters in a global age: What's changed and why it matters, Media, War \& Conflict, 7, 3-22, 2014.

Cox, R. S., Long, B. C., Jones, M. I., and Handler, R. J.: Sequestering of suffering: Critical discourse analysis of natural disaster media coverage, J. Health Psychol., 13, 469-480, 2008.

CRED: The International Disaster Database, Centre for Research on the Epidemiology of Disasters, Brussels, Belgium, available at: http://www.emdat.be/ (last access: 17 April 2017), 2017.

Devès, M.: La question du réel: de la science à la catastrophe, Recherches en Psychanalyse, 20, 107-116, 2015.

Earle, P., Guy, M., Buckmaster, R., Ostrum, C., Horvath, S., and Vaughan, A.: OMG earthquake! Can Twitter improve earthquake response?, Seismol. Res. Lett., 81, 246-251, 2010.

Gaddy, G. D. and Tanjong, E.: Earthquake coverage by the Western press, J. Commun., 36, 105-112, 1987.

Galtung, J. and Ruge, M. H.: The structure of foreign news the presentation of the Congo, Cuba and Cyprus Crises in four Norwegian newspapers, J. Peace Res., 2, 64-90, 1965.

Grasland, C.: International news flow theory revisited through a space-time interaction model: Application to a sample of 320,000 international news stories published through RSS flows by 31 daily newspapers in 2015, Int. Commun. Gaz., https://doi.org/10.1177/1748048518825091, 2019.

Grasland, C., Lamarche-Perrin, R., Loveluck, B., and Pecout, H. International Agenda-setting, the Media and Geography: A multidimensional Analysis of News Flows, L'Espace Géographique, 45, 25-43, 2016.

Haas, J. E., Kates, R. W., and Bowden, M. J.: Reconstruction following disaster, in: Reconstruction following disaster, US The Massachusetts Institute of Technology, 1977.

Harcup, T. and O'Neill, D.: What is news? Galtung and Ruge revisited, Journalism Stud., 2, 261-280, 2001.

Harcup, T. and O'Neill, D.: What is news? News values revisited (again), Journalism Stud., 18, 1470-1488, 2017.

Harris, A. J. L.: Forecast communication through the newspaper part 1: framing the forecaster, B. Volcanol., 77, p. 29, $2015 \mathrm{a}$.

Harris, A. J. L.: Forecast communication through the newspaper part 2: perceptions of uncertainty, B. Volcanol., 77, p. 30, $2015 \mathrm{~b}$.
Hiori, O., Mikami, S., and Miyata, K.: A study of mass media reporting in emergencies, International Journal of Mass Emergencies and Disasters, 3, 21-49, 1985.

Huckin, T.: Textual silence and the discourse of homelessness, Discourse Soc., 13, 347-372, 2002.

Jamieson, T. and Van Belle, D. A.: How Development Affects News Media Coverage of Earthquakes: Implications for Disaster Risk Reduction in Observing Communities, Sustainability, 11, p. 1970, 2019.

Kates, R. W., Colten, C. E., Laska, S., and Leatherman, S. P.: Reconstruction of New Orleans after Hurricane Katrina: a research perspective, P. Natl. Acad. Sci. USA, 103, 14653-14660, 2006.

Kim, K. and Barnett, G. A.: The determinants of international news flow: A network analysis, Commun. Res., 23, 323-352, 1996.

Koopmans, R. and Vliegenthart, R.: Media attention as the outcome of a diffusion process - A theoretical framework and crossnational evidence on earthquake coverage, Eur. Sociol. Rev., 27, 636-653, 2010.

Lamontagne, M., Flynn, B., and Goulet, C.: Facing the communication challenges during an earthquake swarm period, Seismol. Res. Lett., 87, 1-5, 2016.

Le, Q. and Mikolov, T.: Distributed representations of sentences and documents, in: International Conference on Machine Learning, Proceedings of the 31st International Conference on Machine Learning, Beijing, China, JMLR: W\&CP, Vol. 32, 1188-1196, 2014.

Le Texier, M., Devès, M. H., Grasland, C., and De Chabalier, J. B.: Earthquakes media coverage in the digital age, L'Espace Géographique, 45, 5-24, 2016.

McClure, J. and Velluppillai, J.: The effects of news media reports on earthquake attributions and preventability judgments: Mixed messages about the Canterbury earthquake, Australasian Journal of Disaster and Trauma Studies, 2013, 27-36, 2013.

McClure, J., Allen, M. W., and Walkey, F.: Countering fatalism: Causal information in news reports affects judgments about earthquake damage, Basic Appl. Soc. Psych., 23, 109-121, 2001.

Östgaard, E.: Factors influencing the flow of news, J. Peace Res., 2, 39-63, 1965.

Peterson, S.: International news selection by the elite press: A case study, Public Opin. Quart., 45, 143-163, 1981.

Rovai, E. and Rodrigue, C. M.: The Northridge and Ferndale earthquakes: Spatial inequities in media attention and recovery, National Emergency Training Center, 1998.

Searle, J. R. and Willis, S.: The construction of social reality, Simon \& Schuster Inc., New York, USA, 1995.

Segev, E.: International news flow online: Global views with local perspectives, Vol. 19 of Hampton Press communication series: mass communications and journalism, IBSN 143312985X, 9781433129858, 2016.

Simon, A. F.: Television news and international earthquake relief, J. Commun., 47, 82-93, 1997.

Smith, C.: Reporters, news sources, and scientific intervention: the New Madrid earthquake prediction, Public Underst. Sci., 5, 205 216, 1996.

Tan, Y. J. and Maharjan, R.: What googling trends tell us about public interest in earthquakes, Seismol. Res. Lett., 89, 653-657, 2018.

Thanthatep, K., Komany, S., Pauc, J., Kommalien, K., Insisiengmay, T., Sinsupan, T., Keokhamphoui, S., Tartaglione, D., and 
Murphy, K.: Disaster Risk Reduction: Information Kit for Media, scaling-up community-based disaster risk reduction in Lao PDR, Department of Disaster Management and Climate Change, Ministry of Natural Resources and Environment of Lao PDR \& Asian Disaster Preparedness Center, 2016.

Van Belle, D. A.: New York Times and Network TV news coverage of foreign disasters: the significance of the insignificant variables, J. Mass Commun. Q., 77, 50-70, 2000.

Wein, A., Potter, S., Johal, S., Doyle, E., Becker, J. Communicating with the public during an earthquake sequence: improving communication of geoscience by coordinating roles, Seismol. Res. Lett., 87, 112-118, 2016.

Wilks, D. S.: Cluster analysis, Chapter 15 - Cluster analysis, in: Statistical methods in the atmospheric science, International geophysics series, Vol. 100, Elsevier Inc., USA, 100, 603-616, https://doi.org/10.1016/B978-0-12-385022-5.00015-4, 2011.
Wood, M. M., Kano, M., Mileti, D. S., and Bourque, L. B.: Reconceptualizing household disaster readiness: The "Get Ready" pyramid, Journal of Emergency Management, 7, 25-37, 2009.

Wood, M. M., Mileti, D. S., Kano, M., Kelley, M. M., Regan, R., and Bourque, L. B.: Communicating Actionable Risk for Terrorism and Other Hazards, Risk Anal., 32, 601-615, 2012.

$\mathrm{Wu}, \mathrm{H}$. D.: Systemic determinants of international news coverage: A comparison of 38 countries, J. Commun., 50, 110-130, 2000. 